Skład gatunkowy fitoplanktonu w jeziorze podgrzewanym przez elektrownię cieplną oraz w jeziorach o normalnej temperaturze Specific composition of phytoplankton in a lake warmed by waste water from a thermoelectric plant and lakes with a normal temperature

\title{
J. PÓLTORACKA
}

Przedstawiono wyniki całorocznych badań składu gatunkowego siatkowego planktonu roślinnego w jeziorze podgrzewanym przez elektrownię cieplną oraz $\mathrm{w}$ jeziorach o normalnej temperaturze. $\mathrm{W}$ jeziorze podgrzewanym temperatura wahała się $\mathrm{w}$ granicach $7,4-27,5^{\circ} \mathrm{C}$, natomiast w ,normalnym”, nie podgrzewanym jeziorze $0,8-20,7^{\circ} \mathrm{C}$. Najistotniejszymi cechami wyróżniającymi jezioro podgrzewane spośród pozostałych były: 1) znacznie wyższa ogólna liczba gatunków glonów, głównie zielenic, 2) brak wahań sezonowych zarówno w ogólnej liczbie gatunków fitoplanktonu, jak również w obrębie ważniejszych jego gromad: okrzemek, zielenic, sinic, 3) duża liczba gatunków zielenic utrzymująca się w ciągu całego okresu badań. Stwierdzono, że wzrostowi temperatury przekraczającemu górne granice temperatur spotykanych w normalnych jeziorach towarzyszyło dalsze zwiększanie ogólnej liczby komponentów fitoplanktonu, przede wszystkim zielenic, głównie z rzędu Chlorococcales.

W okresie od V.1965-IV.1966 r. przeprowadzano wstępną ocenę składu gatunkowego planktonu roślinnego trzech jezior okolic Konina: Licheńskiego, Mikorzyńskiego, Ślesińskiego (Tab. 1) charakteryzujących się różną temperaturą spowodowaną działalnością elektrowni Konin. Badania oparto na materiałach zbieranych siatką z gazy młynarskiej Nr 25 $\mathrm{w}$ miesięcznych odstępach.

Najwyższy zakres temperatur $\left(7,4-27,5^{\circ} \mathrm{C}\right)$ posiadało jez. Licheńskie, będące bezpośrednim odbiornikiem wód podgrzanych przez elektrownię Konin; najniższe natomiast ,normalne" temperatury wykazywało jez. Slesińskie $\left(0,8-20,7^{\circ} \mathrm{C}\right)$ nie pozostające pod wpływem wód zrzutowych. Różnice między temperaturą obu jezior wynosiły wg $\mathrm{P}$ a t a l a s a (rękopis): zimą $6,6-9,2^{\circ} \mathrm{C}$; wiosną $6,7-9,6$; latem $5,9-6,7$; jesienią $7,2-9,1$.

Jezioro Mikorzyńskie pozostawało w nieznacznym stopniu pod wpływem wód podgrzanych, czego wyrazem były wyższe temperatury w poszczególnych miesiącach. Różnice temperatury $w$ porównaniu $\mathrm{z}$ jez, Ślesińskim wynosiły $\mathrm{w}$ różnych sezonach $0,2-2,2^{\circ} \mathrm{C}$. 
Tabe

Skład siatkowego planktonu roślinnego trzech jezior koło Konina Net phytoplankton composition of three lakes near Konin in the whole

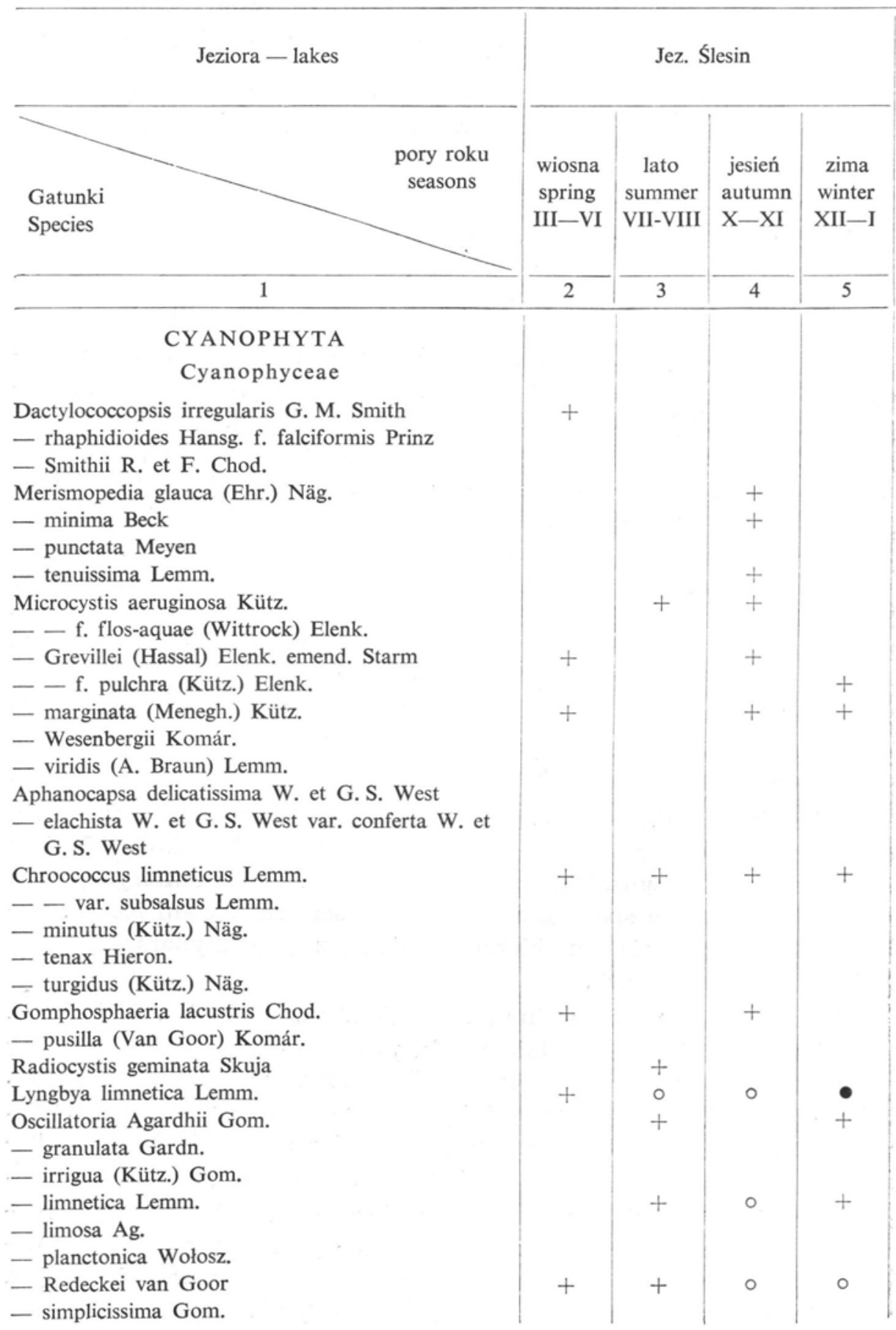


la 1

w całym słupie wody w okresie od 6.V.1965-1.IV.1966r.

column of water in the period from 6.V.1965-1.IV.1966

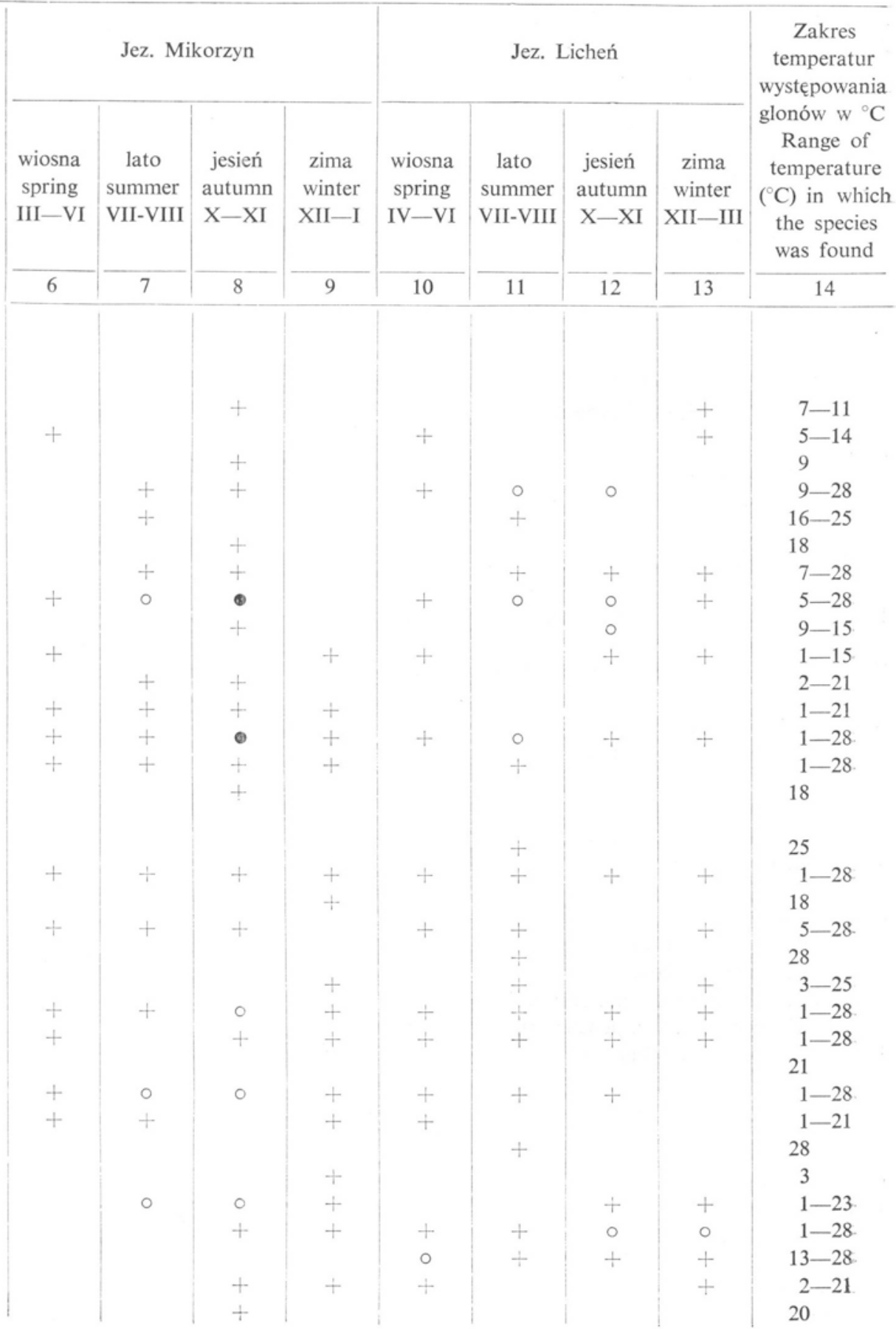




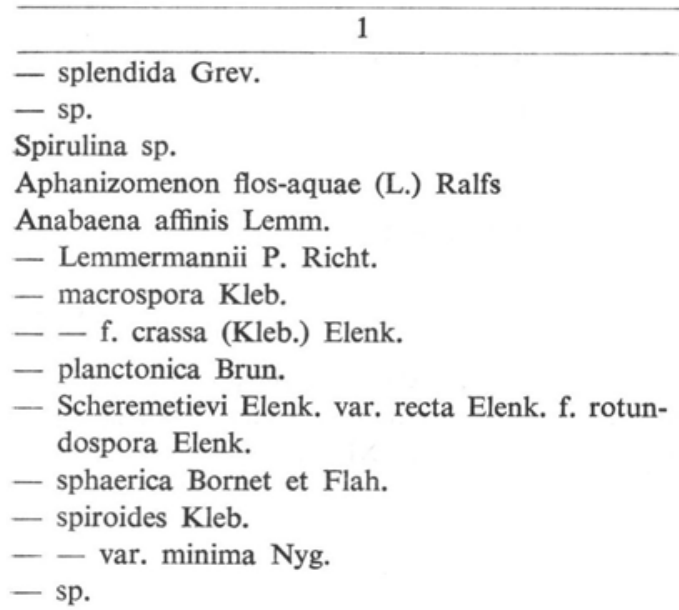

\section{EUGLENOPHYTA}

\section{Euglenophyceae}

Euglena acus Ehr.

- oxyuris Schmarda

- spirogyra Ehr. var. laticlavius (Hübn.) Lemm.

- - var. fusca Klebs

- tripteris (Duj.) Klebs var. maior Swir.

- sp.

Phacus longicauda (Ehr.) Duj. var. tortus Lemm. - pleuronectes (Muell.) Duj.

Trachelomonas granulosa Playf. var. subglobosa Playf.

- intermedia Dang. var. papillifera Popova

- hispida (Perty) Stein emend. Defl.

- - var. coronata Lemm.

- - var. granulata Playf.

- - var. macropunctata Skv.

- - var. spinulosa Skv.

- - var. volicensis Dreż.

- volvocina Ehr.

- - var. derephora Conrad

- - var. punctata Playf.

- - var. subglobosa Lemm. sens Swir.

- volvocinopsis Swir. var. punctata (Roll) Popova

Monomorphina pyrum (Ehr.) Mereschk.

\section{PYRROPHYTA \\ Dinophyceae}

Glenodinium sp.

Peridinium aciculiferum Lemm.

- cinctum (O.F.M.) Ehr.

- latum Pauls.

- Willei Huitf. - Kaas

- Volzii Lemm.

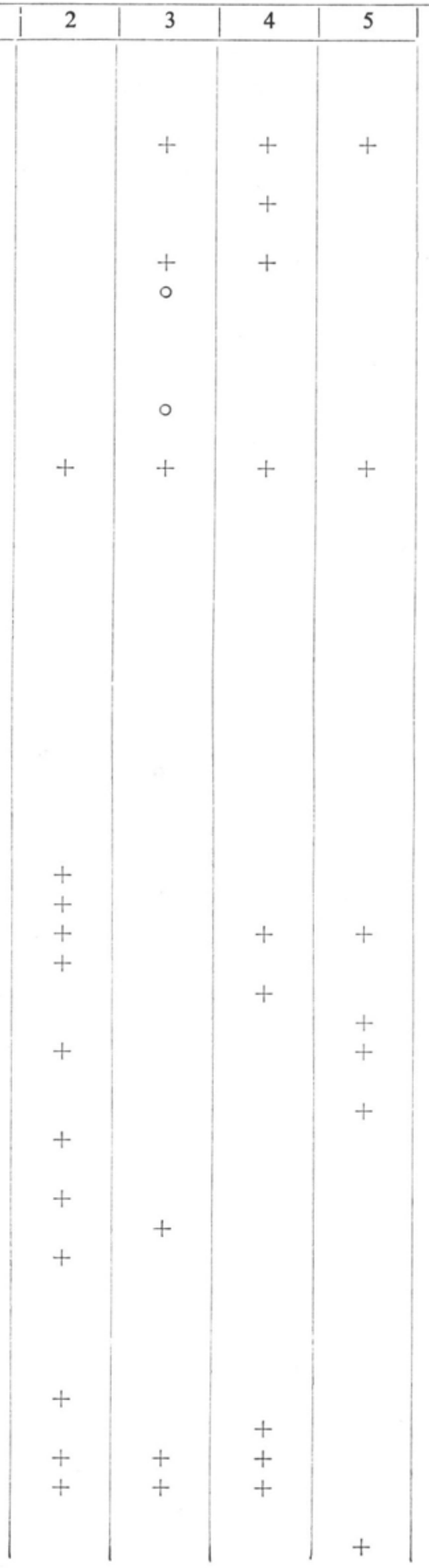




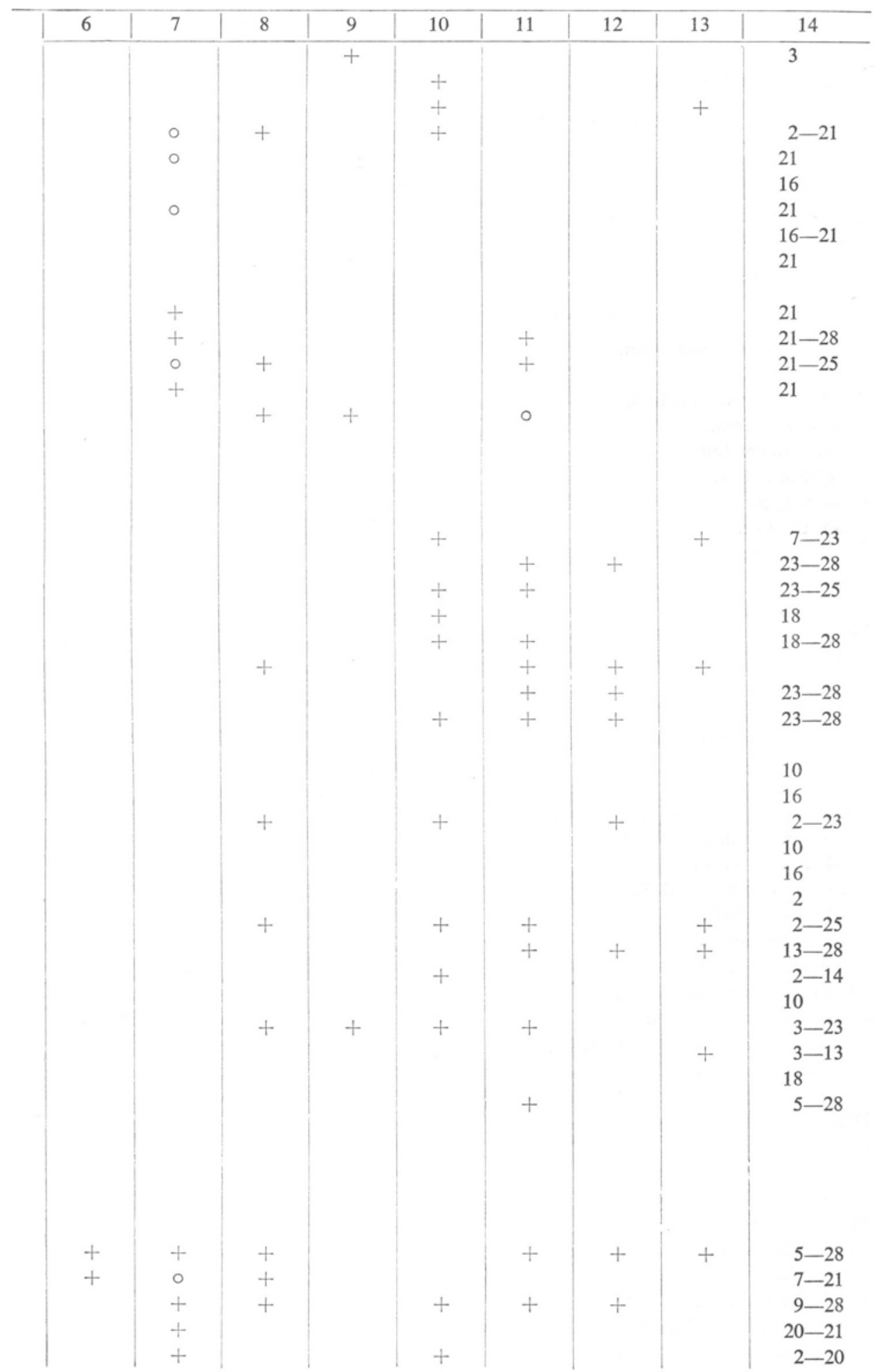


- sp.

Ceratium hirundinella (O.F.M.) Bergh

\section{CHRYSOPHYTA}

1. Xanthophyceae

Dichotomococcus elongatus Fott

Ophiocytium capitatum Wolle var. longispinum (Möb.) Lemm.

Tribonema subtilissimum Pasch.

\section{Chrysophyceae}

Mallomonas producta Iwan.

- sp.

Dinobryon bavaricum Imh.

- divergens Imh.

- cylindricum Imh.

- sertularia Ehr.

- - var. protuberans (Lemm.) Kreig.

- sociale Ehr.

- - var. stipitatum (Stein) Lemm.

\section{Bacillariophyceae}

Melosira ambigua (Grun.) O. Müll.

- arenaria Moore

- Binderana Kütz.

- granulata (Ehr.) Ralfs

- - var. angustissima (O. Müll.) Hust.

- italica (Ehr.) Kütz.

- varians Ag.

Stephanodiscus astraea (Ehr.) Grun.

- - var. minutulus (Kütz.) Grun.

- Hantzschii Grun.

Cyclotella comta (Ehr.) Kütz.

- glomerata Bachm.

- Meneghiniana Kütz.

- operculata (Ag.) Kütz.

Rhizosolenia longiseta Zach.

Attheya Zachariasii Brun

Tabellaria fenestrata (Lyngb.) Kütz.

- flocculosa (Roth) Kütz.

- - var. asterionelloides (Grun. in V. H.) Knud.

Diatoma elongatum (Lyngb.) Ag.

- vulgare Bory

- - var. lineare Grun.

- - var. productum Grun.

Meridion circulare Ag.

Asterionella formosa Hass.

- gracillima (Hantzsch) Heib.

Synedra acus Kütz.

- - var. angustissima Grun.

- - var. radians (Kütz.) Hust. 


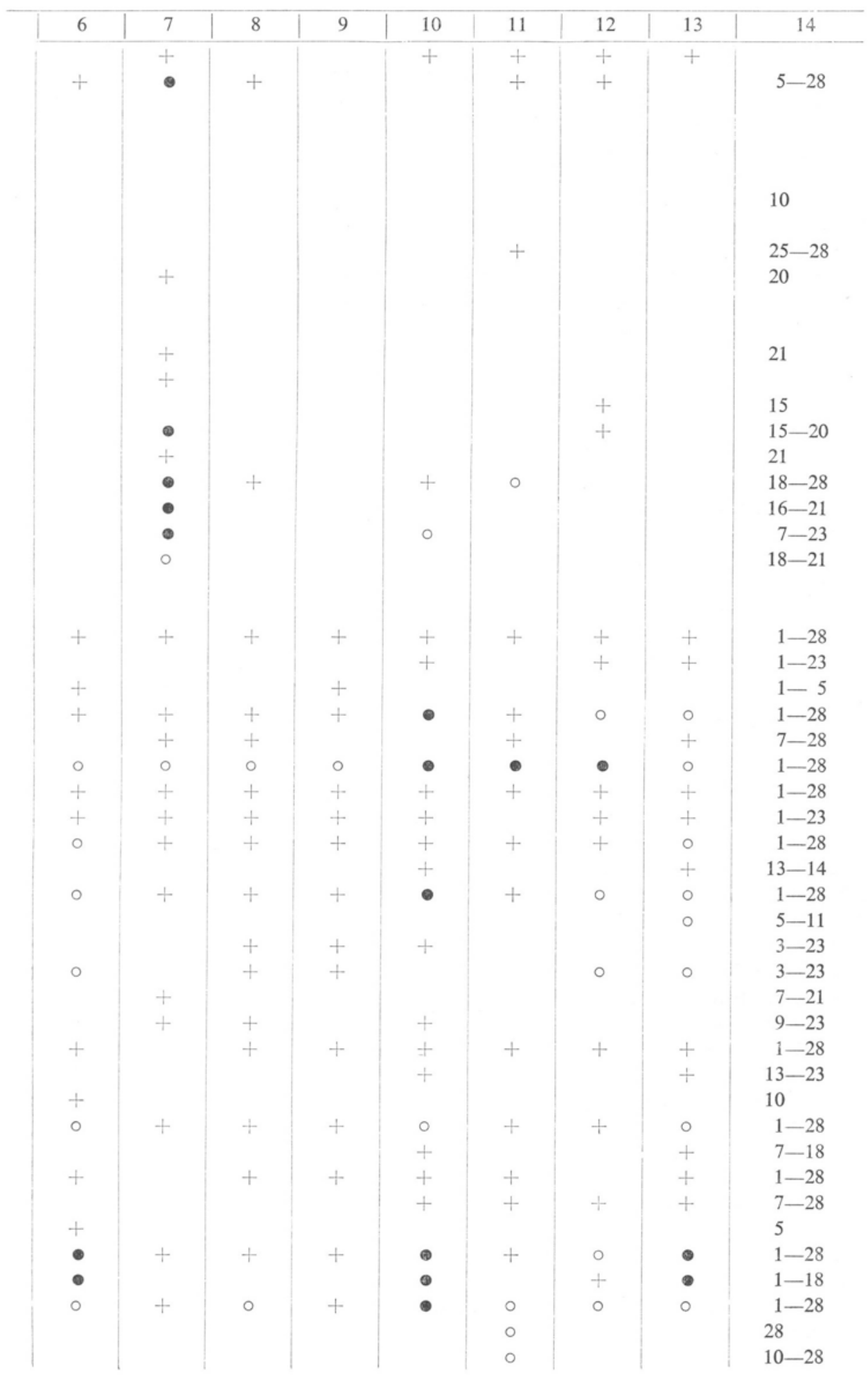




1

- berolinensis Lemm.

- capitata Ehr.

- montana Krasske

- parasitica (W. Sm.) Hust.

- - var. subconstricta Grun.

- ulna (Nitzsch) Ehr.

Fragilaria bidens Heib.

- brevistriata Grun.

- capucina Desm.

- - var. mesolepta Rabh.

- construens (Ehr.) Grun.

- - var. binodis (Ehr.) Grun.

- - var. exigua (W. Sm.) Schulz

- crotonensis Kitt.

- pinnata Ehr.

- virescens Ralfs

- - var. mesolepta v. Schörf.

_ _ var. subsalina Grun.

- sp.

Cocconeis diminuta Pant.

- pediculus Ehr.

- placentula Ehr.

- - var. euglypta (Ehr.) $\mathrm{Cl}$.

- - var. intermedia (Hérib. et Perag.) $\mathrm{Cl}$.

Rhoicosphenia curvata (Kütz.) Grun.

Achnanthes exigua Grun.

- lanceolata (Bréb.) Grun.

_ - f. capitata O. Müll.

- - var. elliptica $\mathrm{Cl}$.

Mastogloia Smithii Thw. var. amphicephala Grun.

Gyrosigma acuminatum (Kütz.) Rabh.

- attenuatum (Kütz.) Rabh.

Diploneis elliptica (Kütz.) $\mathrm{Cl}$.

Neidium affine (Ehr.) Cl. var. amphirhynchus (Ehr.) $\mathrm{Cl}$.

- dubium (Ehr.) $\mathrm{Cl}$.

- $-\mathrm{f}$. constrictum Hust.

— iridis (Ehr.) $\mathrm{Cl}$.

- - f. vernale Reich.

- productum (W. Sm.) Cl.

Pinnularia gentilis (Donk.) $\mathrm{Cl}$.

- gibba Ehr.

- - var. parva (Ehr.) Grun.

- maior (Kütz.) Cl.

- - var. lacustris Meist.

- nobilis Ehr.

- viridis (Nitzsch) Ehr. var. intermedia Cl.

Caloneis amphisbaena (Bory) $\mathrm{Cl}$.

- Schumanniana (Grun.) Cl. var. biconstricta Grun.

- silicula (Ehr.) $\mathrm{Cl}$.

- - var. tumida Hust.

2 3

$+$

$+$

$\circ$

$+$

$+$

$+$

$+$

$+$

$+$

$+$

$+$

$+$

$+$

$+$

$+$

$+$

$+$

$+$

$+$

$+$

$+$

$+$

$+$

$+$

$+$

$+$

$+$

$+$

$+$

$+$

$+$

$+$

$+$

$+$

$+$

$+$ 


\begin{tabular}{|c|c|c|c|c|c|c|c|c|}
\hline 6 & 7 & 8 & 9 & 10 & 11 & 12 & 13 & 14 \\
\hline+ & + & & & + & $\circ$ & & & $5-25$ \\
\hline+ & & + & + & + & + & + & + & $1-28$ \\
\hline & & + & & & & & & 18 \\
\hline & & + & & + & & & + & $7-14$ \\
\hline 0 & + & + & & & & & & 18 \\
\hline 0 & + & 0 & 0 & $\begin{array}{l}0 \\
+\end{array}$ & + & + & $\circ$ & $1-28$ \\
\hline & & + & & & & & & $\begin{array}{l}5-23 \\
9\end{array}$ \\
\hline$\circ$ & + & + & + & + & + & + & + & $1-28$ \\
\hline+ & & + & + & + & & + & + & $3-23$ \\
\hline & & + & + & + & + & + & + & $1-25$ \\
\hline & & + & + & & & & & $3-18$ \\
\hline & & + & & + & + & + & + & $7-25$ \\
\hline 0 & + & + & + & $\circ$ & + & + & + & $1-28$ \\
\hline+ & & + & & & + & + & + & $5-28$ \\
\hline+ & & + & + & & & & & $1-18$ \\
\hline+ & & & + & & & & & $3-10$ \\
\hline & & & & & & & & 21 \\
\hline & & + & & & & & & 18 \\
\hline & + & + & & + & + & + & + & $1-28$ \\
\hline+ & & + & + & + & + & + & + & $1-28$ \\
\hline & & + & & & & + & + & $5-23$ \\
\hline+ & + & + & + & + & + & + & + & $1-28$ \\
\hline+ & + & + & + & + & + & + & + & $1-28$ \\
\hline & & + & & & & 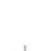 & & 9 \\
\hline & & & & & & + & + & $\begin{array}{c}15-23 \\
5\end{array}$ \\
\hline & & + & & & & & & 18 \\
\hline & & + & + & & & & + & $3-18$ \\
\hline & & + & + & + & & & + & $1-23$ \\
\hline+ & + & + & + & + & + & + & + & $1-28$ \\
\hline+ & & + & & + & + & + & + & $1-25$ \\
\hline & & & & & & & & 16 \\
\hline+ & & + & & & & & & $5-18$ \\
\hline & & & & & + & & + & $7-25$ \\
\hline & & & & & + & + & & $15-28$ \\
\hline 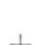 & & & + & & & + & & $3-24$ \\
\hline+ & & + & & + & & & & $10-18$ \\
\hline & & & & & & & & $\begin{array}{r}14 \\
5\end{array}$ \\
\hline & & & & + & & & & 14 \\
\hline & & & & + & & + & + & $13-23$ \\
\hline & & + & & + & & + & + & $9-23$ \\
\hline & & & & & & & & 16 \\
\hline+ & & + & & + & & & & $5-23$ \\
\hline & & & & + & & + & & 15 \\
\hline & & & & $T$ & & $T$ & & 7 \\
\hline
\end{tabular}




\section{1}

Stauroneis acuta W. Sm.

- anceps Ehr.

- inflata Heid.

- legumen Ehr.

- phoenicenteron Ehr.

Anomoeoneis sphaerophora (Kütz.) Pfitz.

Navicula anglica Ralfs

- bacillum Ehr.

_ - var. Gregoryana Grun.

- cincta (Ehr.) Kütz. var. Heufleri Grun.

- cryptocephala Kütz.

- cuspidata Kütz.

- - f. primigena Dipp.

- - var. ambigua (Ehr.) $\mathrm{Cl}$.

- dicephala (Ehr.) W. Sm.

- exigua (Greg.) O. Müll.

- gastrum Ehr.

- gracilis Ehr.

- Hungarica Grun. var. capitata (Ehr.) Cl.

- lacustris Greg.

- menisculus Schum.

- oblonga Kütz.

- placentula (Ehr.) Grun.

- - f. latiuscula (Grun.) Meist.

— - f. rostrata Mayer

- popula Kütz. var. capitata Hust.

- - var. elliptica Hust.

- - var. mutata (Krasske) Hust.

- - var. rectangularis (Greg.) Grun.

— radiosa Kütz.

- Reinhardtii Grun.

- rhynchocephala Kütz.

- salinarum Grun. f. capitata Schulz.

- scutelloides W. Sm.

- tuscula (Ehr.) Grun.

- - var. rostrata Hust.

— viridula Kütz. var. slesvicensis (Grun.) Cl.

- sp.

Cymbella affinis Kütz.

- aspera (Ehr.) Cl.

- cistula (Hemp.) Grun.

— - var. maculata (Kütz.) V. H.

- cuspidata Kütz.

- Ehrenbergii Kütz.

- helvetica Kütz.

- lanceolata (Ehr.) V. H.

- prostrata (Beikeley) $\mathrm{Cl}$.

- tumida (Bréb.) V. H.

- turgida (Greg.) Cl.

- ventricosa Kütz.

Amphora Normanii Rabh. 



1
- ovalis Kütz.
- - var. pediculus Kütz.
- perpusilla Grun.
- veneta Kütz.

Gomphonema acuminatum Ahr.

- - var. Brébissonii (Kütz.) Cl.

- - var. coronatum (Ehr.) W. Sm.

- - var. trigonocephalum (Ehr.) Grun.

- augur Ehr.

- capitatum Ehr.

- constrictum Ehr.

- lanceolatum Ehr.

- longiceps Ehr. var. subclavatum Grun.

- olivaceum (Lyngb.) Kütz.

- - var. calcareum $\mathrm{Cl}$.

Epithemia Hyndemannii W. Sm.

- intermedia Fricke

- sorex Kütz.

- - var. gracilis Hust.

— turgida (Ehr.) Kütz.

- - var. granulata (Ehr.) Grun.

- zebra (Ehr.) Kütz.

- - var. porcellus (Kütz.) Grun.

- - var. saxonica (Kütz.) Grun.

Rhopalodia gibba (Ehr.) O. Müll.

- - var. ventricosa (Ehr.) Grun.

Hantzschia elongata Grun.

Nitzschia acicularis W. Sm.

- acuta Hantzsch

- angustata (W. Sm.) Grun.

- flexa Schum.

- frustulum (Kütz.) Grun.

- holsatica Hust.

- palea (Kütz.) W. Sm.

- sigmoidea (Ehr.) W. Sm.

- sublinearis Hust.

- thermalis Kütz.

- trybionella Hantzsch var. levidensis (W. Sm.) Grun.

- vermicularis (Kütz.) Grun.

- sp.

Cymatopleura elliptica (Bréb.) W. Sm.

- - var. nobilis (Hantzsch) Hust.

- solea (Bréb.) W. Sm.

- - var. apiculata (W. Sm.) Ralfs

- - var. clavata O. Müll.

- - var. gracilis Grun.

Surirella biseriata Bréb.

- - var. bifrons (Ehr.) Hust.

- - var. rostrata Schulz

- linearis W. Sm.

2

3 


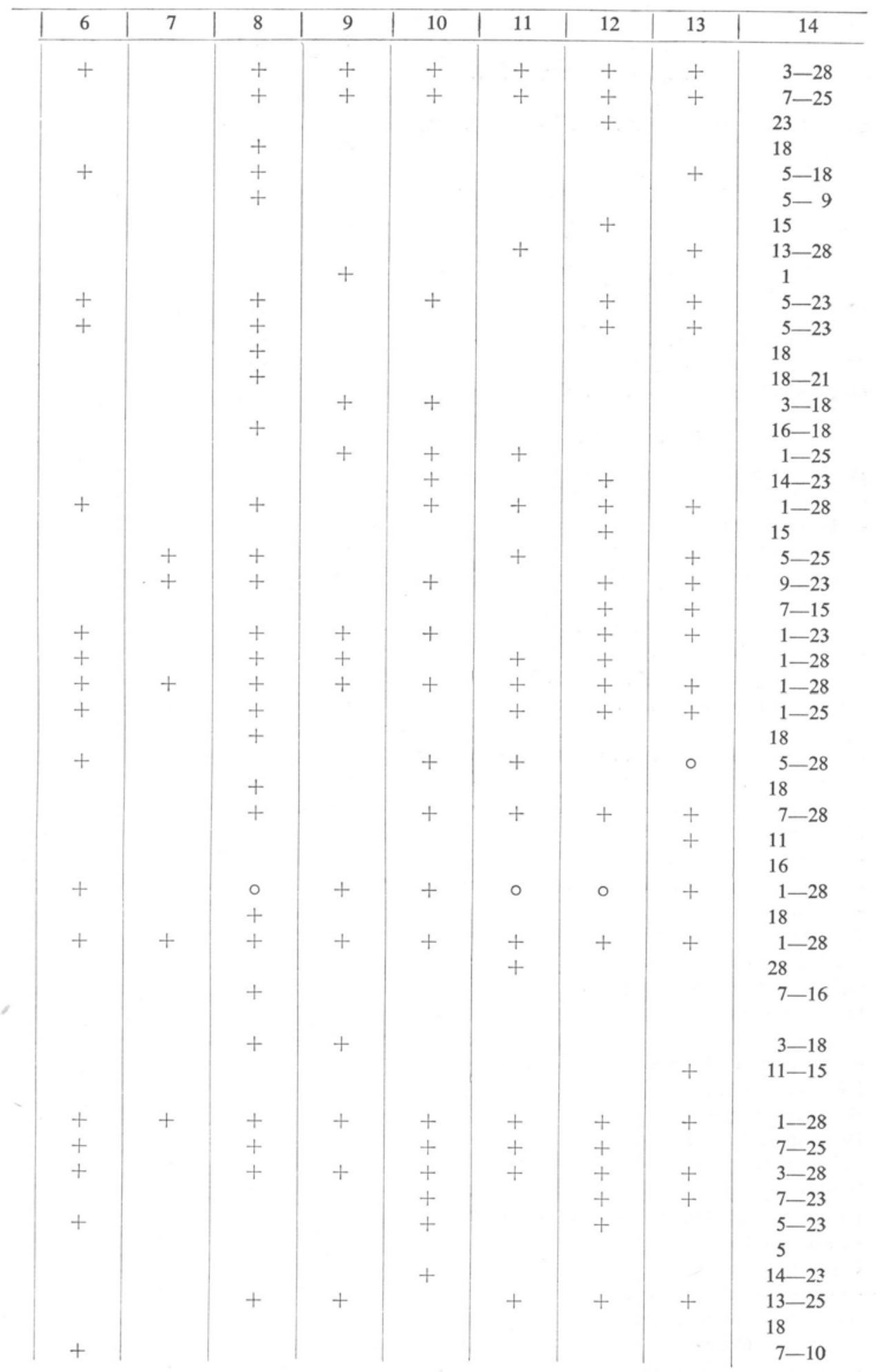




$\frac{1}{\text { - robusta Ehr. var. splendida (Ehr.) V. H. }}$

- tenera Greg.

Campylodiscus noricus Ehr. var. hibernica (Ehr.) Grun.

\section{CHLOROPHYTA}

Chlorophyceae

\section{Volvocales}

Pandorina morum Bory

Eudorina elegans Ehr.

Tetraspora simplex Korsch.

Gemellicystis neglecta Teil. em. Skuja

\section{Chlorococcales}

Pediastrum angulosum (Ehr.) Menegh.

- biradiatum Meyen

- boryanum (Turp.) Menegh.

- - var. longicorne Racib.

- _ - f. granulata Racib.

- duplex Meyen

- - var. clathratum (A. Braun) Lag.

- - var. cohaerens Bohl.

- - var. gracillimum W. et G. S. West

- - var. reticulatum Lag.

- Kawraiskyi Schmidle

- simplex (Meyen) Lemm. var. duodenarium (Bailey) Rabh.

- Tetras (Ehr.) Ralfs

Micractinium pusillum Fres.

- - var. elegans G. M. Smith

Golenkinia paucispina W. et G. S. West

- radiata Chod.

Polyedriopsis spinulosa Schmidle

Treubaria triappendiculata Bern.

Calyptrobactron indutum Geitl.

Gloeocystis ampla Kütz.

— gigas (Kütz.) Lag.

- planctonica (W. et G. West) Lemm.

Sphaerocystis Schroeteri Chod.

Botryococcus Braunii Kütz.

Dictyosphaerium Ehrenbergianum Näg.

- pulchellum Wood

Westella botryoides (W. West) Wild

Lagerheimia citriformis (Snow) G. M. Smith

- subsalsa Lemm.

Oocystis Borgei Snow

- crassa Wittr.

- gloeocystiformis Borge

- lacustris Chod.

- parva W. et G. S. West

2

$2 \mid 3$

$+$

4




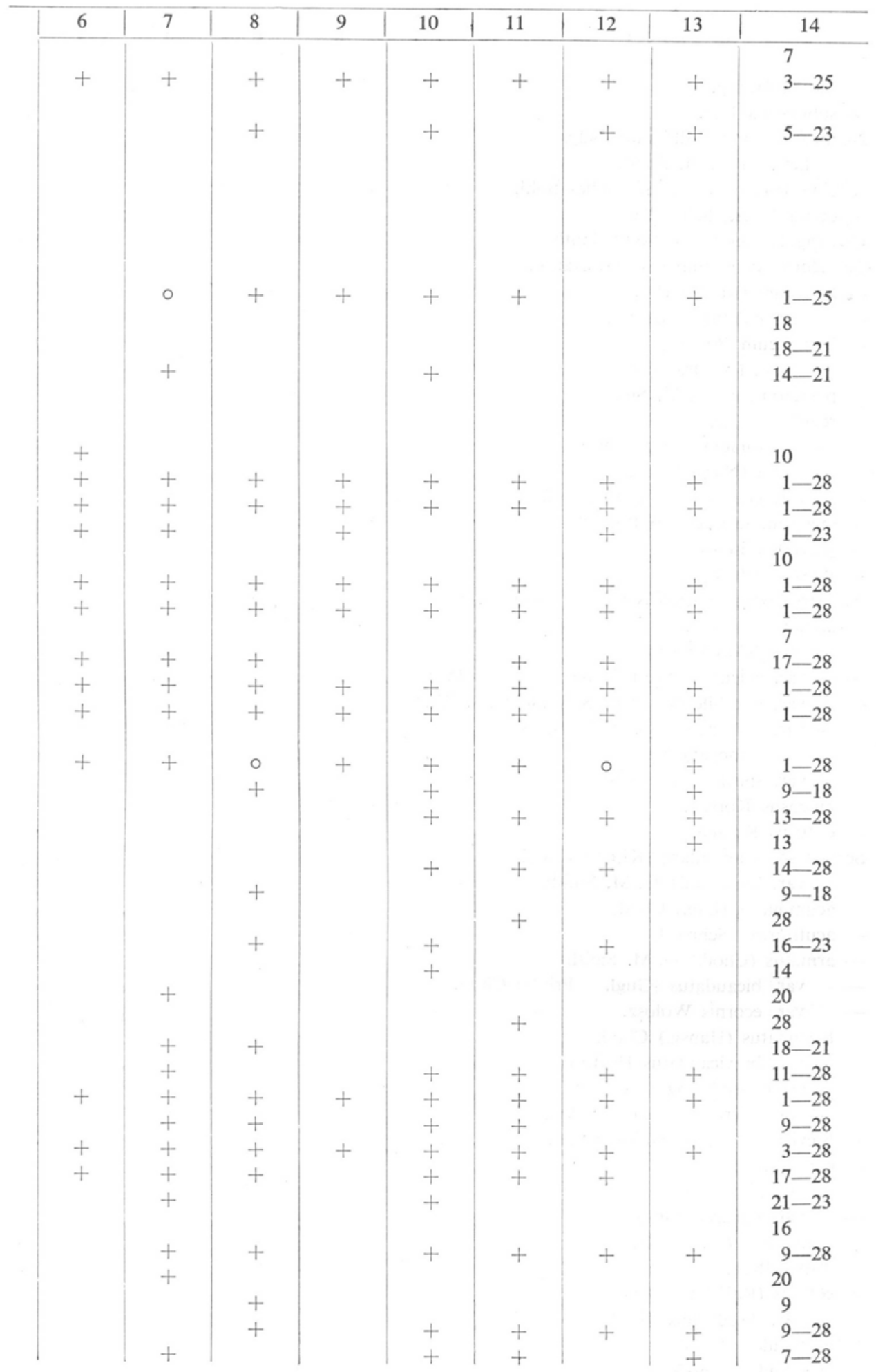


- pusilla Hansg.

- submarina Lag.

Nephrocytium Agardhianum Näg.

- limneticum G. M. Smith

Kirchneriella contorta (Schmidle) Bohl.

- obesa (West) Schmidle

Quadrigula lacustris (Chod.) Smith

Tetraëdron caudatum (Corda) Hansg.

- hastatum (Rabh.) Hansg.

- - var. palatinum Lemm.

- limneticum Borge

- minimum (A. Br.) Hansg.

- planctonicum G. M. Smith

- regulare Kütz.

- - var. torsum (Turner) Brun.

- trigonum (Näg.) Hansg.

- - var. gracile (Reinsch) de Toni

Selenastrum Bibraianum Reinsch

- gracile Reisch

- Westii Fritsch

Ankistrodesmus acicularis (A. Br.) Korsch.

- arcuatus Korsch.

- falcatus (Corda) Ralfs

- - var. acicularis West $\mathrm{f}$. longissima Printz

- - var. mirabile (W. et G. S. West) G. S. West

- - var. setiformis Nyg. f. brevis Nyg.

- $-\mathrm{f}$. elongata Nyg.

- - var. spirilliformis West

- mucosus Korsch.

- obtusus Korsch.

Scenedesmus abundans (Kirch.) Chod.

- - var. longicauda G. M. Smith

- acuminatus (Lag.) Chod.

- acutiformis Schroed.

- armatus (Chod.) G. M. Smith

- - var. bicaudatus (Gugl. — Printz) Chod.

- - var. ecornis Wołosz.

- bicaudatus (Hansg.) Chod.

- - var. brevicaudatus Hortob.

- bijuga (Turp.) Lag.

- - var. alternans (Reinsch) Borge

- brevispina (G. M. Smith) Chod.

- carinatus (Lemm.) Chod.

- denticulatus Lag.

- - var. linearis Hansg.

- dimorphus (Turp.) Kütz.

- dispar Bréb.

- ecornis (Ralfs) Chod.

- - var. disciformis Chod.

- ellipsoideus Chod.

- intermedius Chod.

3

\begin{tabular}{l|l}
4 & 5
\end{tabular}




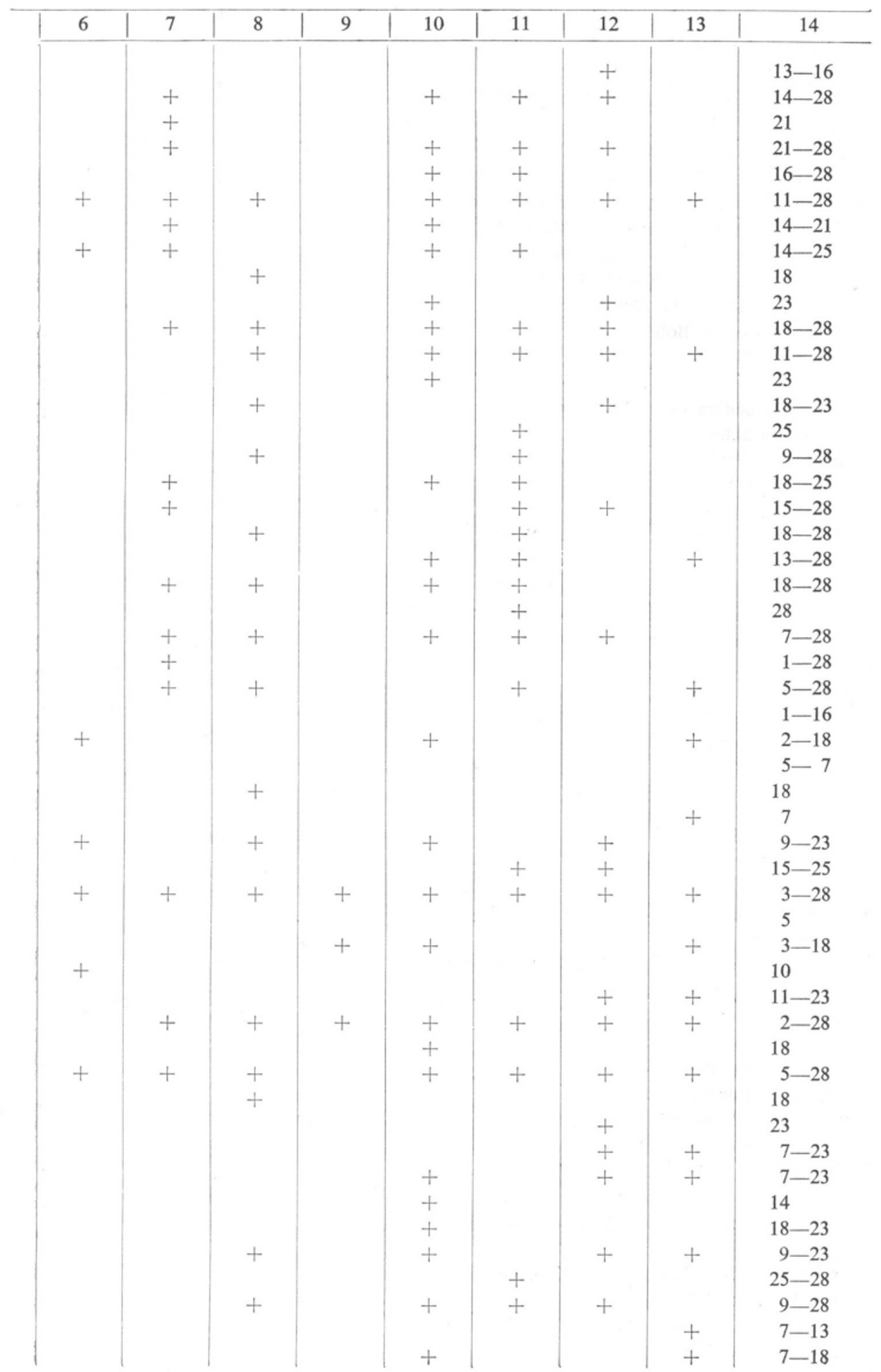


1
$-\quad$ var. balatonicus Hortob.
- - var. bicaudatus Hortob.

- longus Meyen var. Naegellii (Bréb.) G. M. Smith

— opoliensis P. Richt.

- platydiscus (G. M. Smith) Chod.

- quadricauda (Turp.) Bréb.

- - var. biornatus Kiss f. giganticus Uherkov.

- - var. longispina (Chod.) G. M. Smith

- - var. maximus W. et G. S. West

- - var. quadrispina (Chod.) G. M. Smith

— - var. Westii G. M. Smith

- serratus (Corda) Bohl.

- spinosus Chod.

- sp.

Crucigenia crucifera (Wolle) Collins

- fenestrata Schmidle

— irregularis Wille

- quadrata Morren

- rectangularis (Näg.) Gay

- Tetrapedia (Kirchn.) W. et G. S. West

- truncata G. M. Smith

Tetrastrum staurogeniaeforme (Schroed.) Lemm.

Actinastrum Hantzschii Lag.

- - var. fluviatile Schroed.

Coelastrum cambricum Arch.

- microporum Näg.

- proboscideum Bohl.

- reticulatum (Dang.) Senn

\section{Ulotrichales}

Stichococcus bacillaris Näg.

\section{Conjugales}

Spirogyra sp.

Mougeotia sp.

Closterium acerosum (Schrank) Ehr. var. elongatum Bréb.

- aciculare T. West

- gracile Bréb.

- moniliferum (Bory) Ehr.

- Pritchardianum Arch.

Pleurotaenium Trabecula (Ehr.) Näg.

Cosmarium granatum Bréb.

- Meneghinii Bréb.

- protractum (Näg.) de Bary

- punctulatum Bréb. var. subpunctulatum (Nordst.) Borg.

- subprotumidum Nordst. var. Gregorii (Roy et Biss.) W. et G.S. West

Staurastrum Chaetoceras (Schroed.) G. M. Smith

- curvatum W. West 


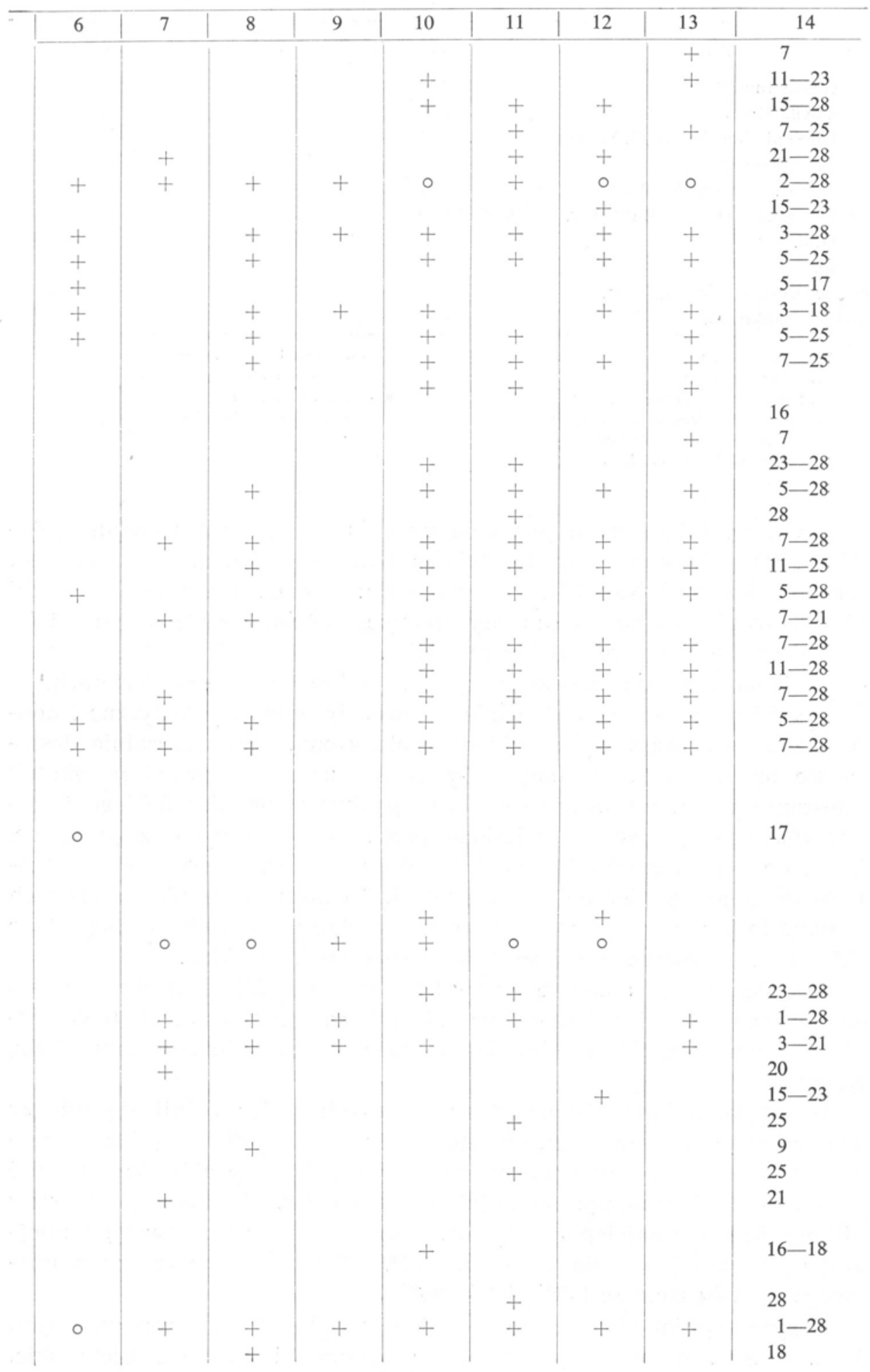




\begin{tabular}{l|l|l|l|l|}
\hline \multicolumn{1}{c|}{ 1 } & 2 & 3 & 4 & 5 \\
\hline - cuspidatum Bréb. & & & & \\
- gracile Ralfs & + & & & \\
- longiradiatum W. et G. S. West & + & + & + & + \\
- paradoxum Meyen & & & & \\
- var. parvum W. West & & & \\
- tetracerum (Kütz.) Ralfs var. validum W. et & & & \\
$\quad \begin{array}{l}\text { G. S. West } \\
\text { sp. }\end{array}$ & & & & \\
$\begin{array}{l}\text { Sphaerozosma exiguum Turn. } \\
\text { zielenice nitkowate }\end{array}$
\end{tabular}

Skala liczebności:

Scale of abundance:

Gatunek spotkany przynajmniej raz:

Species found at least in one sample:

+- w małej liczbie osobników

in small No of individuals
- w średniej liczbie osobników

in medium No of individuals

- w dużej liczbie osobników

in large No of individuals

We wszystkich trzech jeziorach podczas całego okresu badań znaleziono 305 gatunków, a uwzględniając odmiany i formy 414 jednostek taksonomicznych. Największą liczbę jedn. takson. posiadały okrzemki $(44 \%)$, drugie miejsce zajmowały zielenice $(34 \%)$, trzecie sinice $(11 \%)$. Udział pozostałych gromad był niewielki.

Podobne stosunki znaleziono również w poszczególnych jeziorach.

Wśród okrzemek zdecydowanie przeważały gatunki epifityczne i denne stanowiące przypadkowy składnik planktonu. Przypuszczalnie dostały się one do strefy wolnej wody na drodze mechanicznej na skutek mieszania wody, względnie — w przypadku jezior Licheńskiego i Mikorzyńskiego - zostały wniesione przez wody zrzutowe $\mathrm{z}$ płytkiego, bogatego w roślinność wyższą, silnie falującego jez. Pątnowskiego, z którego woda jest pobierana do elektrowni. Ta duża liczba nie związanych $\mathrm{z}$ planktonem okrzemek decydowała w dużym stopniu o bogactwie składu gatunkowego we wszystkich jeziorach konińskich.

Największą liczbę komponentów fitoplanktonu (285) znaleziono w najcieplejszym jez. Licheńskim (ryc. 1), najniższą natomiast (197) w najzimniejszym jez. Ślesińskim, co wiązało się $\mathrm{z}$ najniższą tam liczbą zielenic.

Skład jakościowy fitoplanktonu badanych jezior różnił się między sobą znacznie. Glonów, które występowały we wszystkich jeziorach było zaledwie $29 \%$, przy czym na procent ten składały się głównie okrzemki i zielenice. Przechodząc od najzimniejszego jez. Ślesińskiego, poprzez Mikorzyńskie do najcieplejszego jez. Licheńskiego zwraca uwagę zmniejszający się kolejno udział okrzemek $\left(51^{\%} \%, 47 \%, 42 \%\right)$ na rzecz wzrastającego udziału zielenic $(26 \%, 32 \%, 39 \%)$.

Przyjmując jako kryterium podobieństwa planktonu liczbę wspólnych jedn. takson. najbardziej różniły się jeziora Ślesińskie i Licheńskie. 


\begin{tabular}{|c|c|c|c|c|c|c|c|c|}
\hline 6 & 7 & 8 & 9 & 10 & 11 & 12 & 13 & 14 \\
\hline $\begin{array}{l}+ \\
+\end{array}$ & $\begin{array}{l}+ \\
+ \\
0\end{array}$ & $\begin{array}{l}+ \\
+\end{array}$ & + & $\begin{array}{l}+ \\
+ \\
+\end{array}$ & $\begin{array}{l}+ \\
+ \\
+ \\
+\end{array}$ & $\begin{array}{l}0 \\
+ \\
+ \\
+\end{array}$ & $\begin{array}{l}+ \\
+\end{array}$ & $\begin{array}{r}18-28 \\
1-28 \\
2-21 \\
13-28 \\
9-23 \\
15-28 \\
18\end{array}$ \\
\hline
\end{tabular}

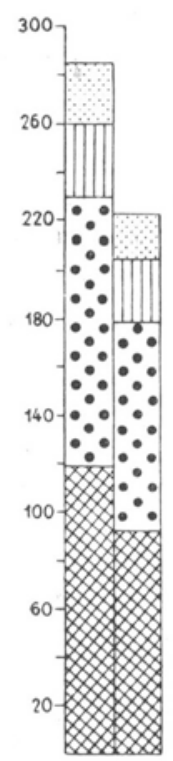

A $B$

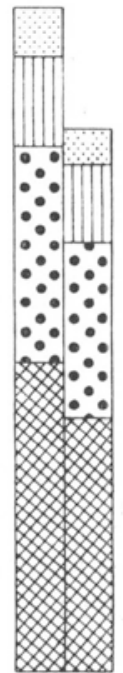

A $B$

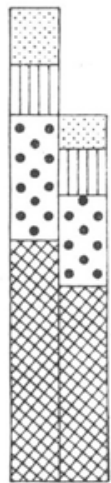

A B

JEZ. LICHENSKIE MIKORZYNSKIE SLESIŃSKIE

A

LICZBA JEDNOSTEK TAKSONOMICZNYCH NUMBER OF TAXA

\section{BACILLARIOPHYCEAE \\ $\because$ CHLOROPHYCEAE}

॥

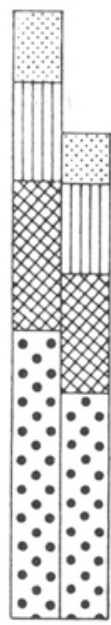

A B

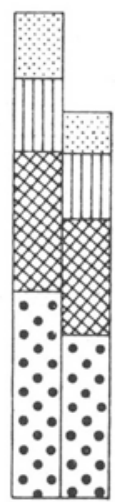

A B

LEMIĘT

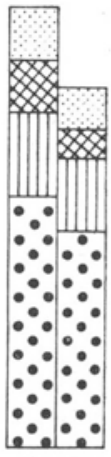

A B

SUKIEL
B LICZBA GATUNKOW
NUMBER OF SPECIES

\section{IIII) CYANOPHYCEAE \\ INNE - OTHERS}

Rys. 1. Liczba gatunków (oraz jednostek taksonomicznych) glonów znaleziona podczas całorocznych badań w jeziorach koło Konina (I) i w jeziorach mazurskich (II) Number of species (and taxa) of Algae found during whole-year investigations in lakes near Konin (I) and in those of the Masurian Lake District (II) 
Stwierdzono w nich tylko $38 \%$ wspólnych jednostek. Znacznie mniej różnił się plankton jezior Licheńskiego i Mikorzyńskiego, w których stwierdzono $50 \%$ wspólnych jednostek.

Różnice w planktonie jezior Slesińskiego i Licheńskiego dotyczyìy głównie zielenic, wśród których tylko $31 \%$ jednostek wystąpiło w obu jeziorach.

W celach porównawczych zestawiono obok jezior konińskich skład gatunkowy fitoplanktonu jednego mezotroficznego oraz dwóch eutroficznych jezior mazurskich (ryc. 1), badanych (P ółtor a cka 1966 oraz materiały nie publikowane) w odstępach dwutygodniowych w cyklu rocznym.

Plankton roślinny jezior mazurskich był jakościowo uboższy w porównaniu $\mathrm{z}$ jeziorami konińskimi. W tych ostatnich grupę najbogatszą w gatunki stanowiły okrzemki, w nieco mniejszym stopniu zielenice, natomiast $\mathrm{w}$ jeziorach mazurskich, niezależnie od ich typu limnologicznego najbogatsze w gatunki były zdecydowanie zielenice. Liczba ich była w przybliżeniu równa, a niekiedy wyższa od znalezionej w jeziorach konińskich. Drugie i trzecie miejsce zajmowały bądź okrzemki, bądź sinice, przy czym okrzemki posiadały w jeziorach mazurskich znacznie mniej przedstawicieli niż w jeziorach konińskich.

W 1913 r. fitoplankton jez. Licheńskiego badała J. W oł o s z y ń s k a ograniczając się do oznaczania form typowo planktonowych. Materiał w ilości 4 prób pochodził z czerwca. Ogółem oznaczyła 29 gatunków glonów. Spośród nich 9 gatunków nie stwierdzono w obecnych badaniach. Są to 4 sinice (Anabaena circinalis Rabh., A. flos-aquae (Lyngb.) Bréb., A. Lemmermannii P. Richt., Gomphosphaeria Naegeliana Lemm.), 3 bruzdnice (Peridinium cinctum (O.F.M.) Ehr., P. Westii Lemm., P. Penardii (Lemm.) Lemm.), 2 okrzemki (Centronella Reicheltii Voigt, Rhizosolenia longiseta Zach.).

Prześledzono w ciągu jednego roku sezonowe zmiany ogólnej liczby gatunków fitoplanktonu, jak również ważniejszych jego gromad (ryc. 2). We wszystkich jeziorach zwraca uwagę przewaga okrzemek podczas całego badanego okresu, szczególnie silnie zaznaczająca się w jeziorach Ślesińskim i Mikorzyńskim. Drugie miejsce pod względem liczby gatunków zajmowały zielenice, szczególnie urozmaicone w jez. Licheńskim, w żadnym $z$ nich jednak nie ulegając większym wahaniom sezonowym. Znacznie uboższe w gatunki sinice wysuwały się na trzecie miejsce, przy czym liczba ich komponentów w różnych porach roku na ogół zmieniała się w niedużym stopniu.

Obok omówionych wyżej wspólnych cech jeziora konińskie różniły się między sobą przebiegiem sezonowych zmian tak ogólnej liczby składników fitoplanktonu, jak również niektórych jego gromad.

Najistotniejszą cechą wyróżniającą jezioro Licheńskie spośród pozostałych była niewiele zmieniająca się w ciągu roku liczba gatunków glo- 

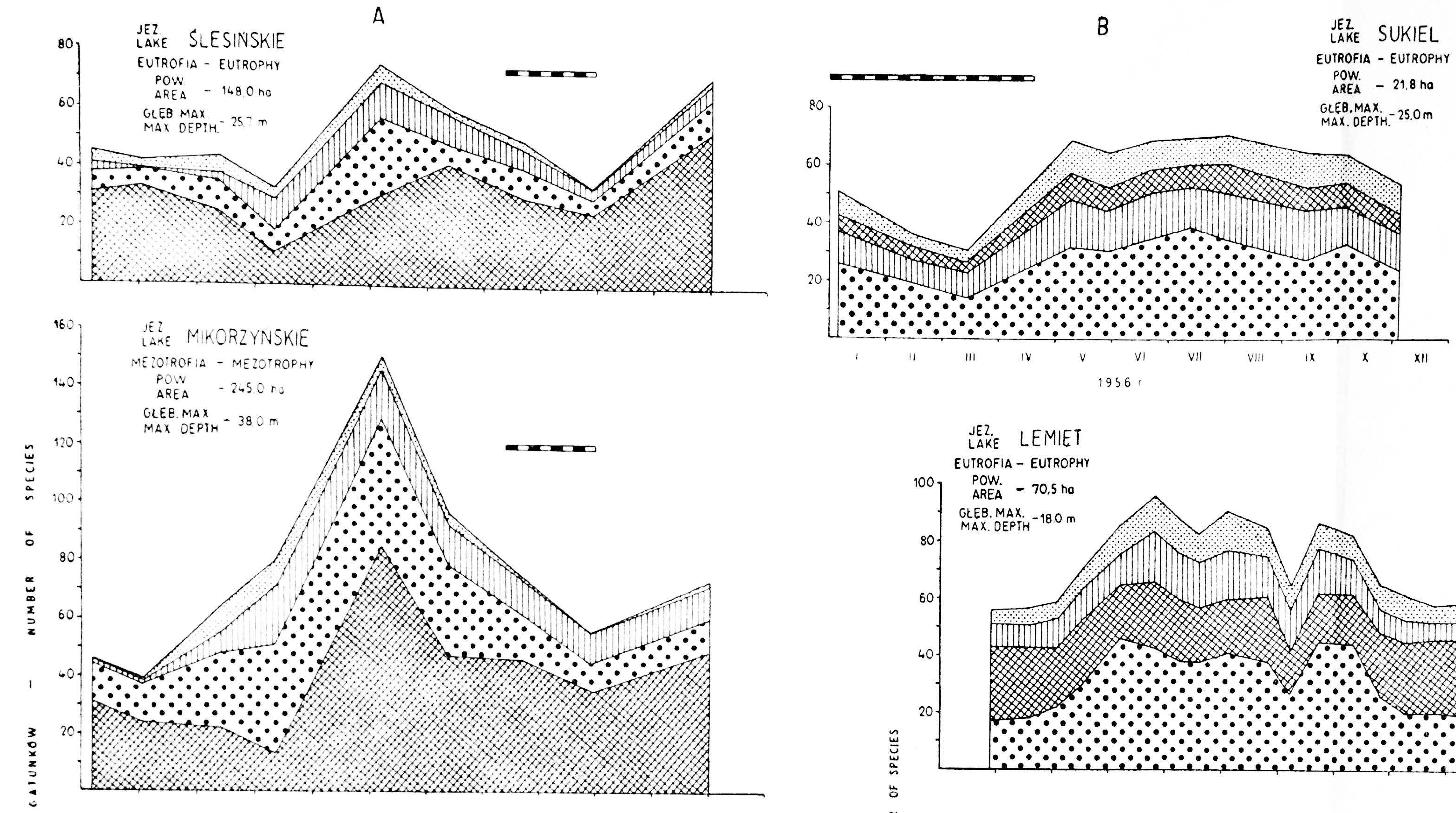

POKRYCIE LOOEM
ILE COVER
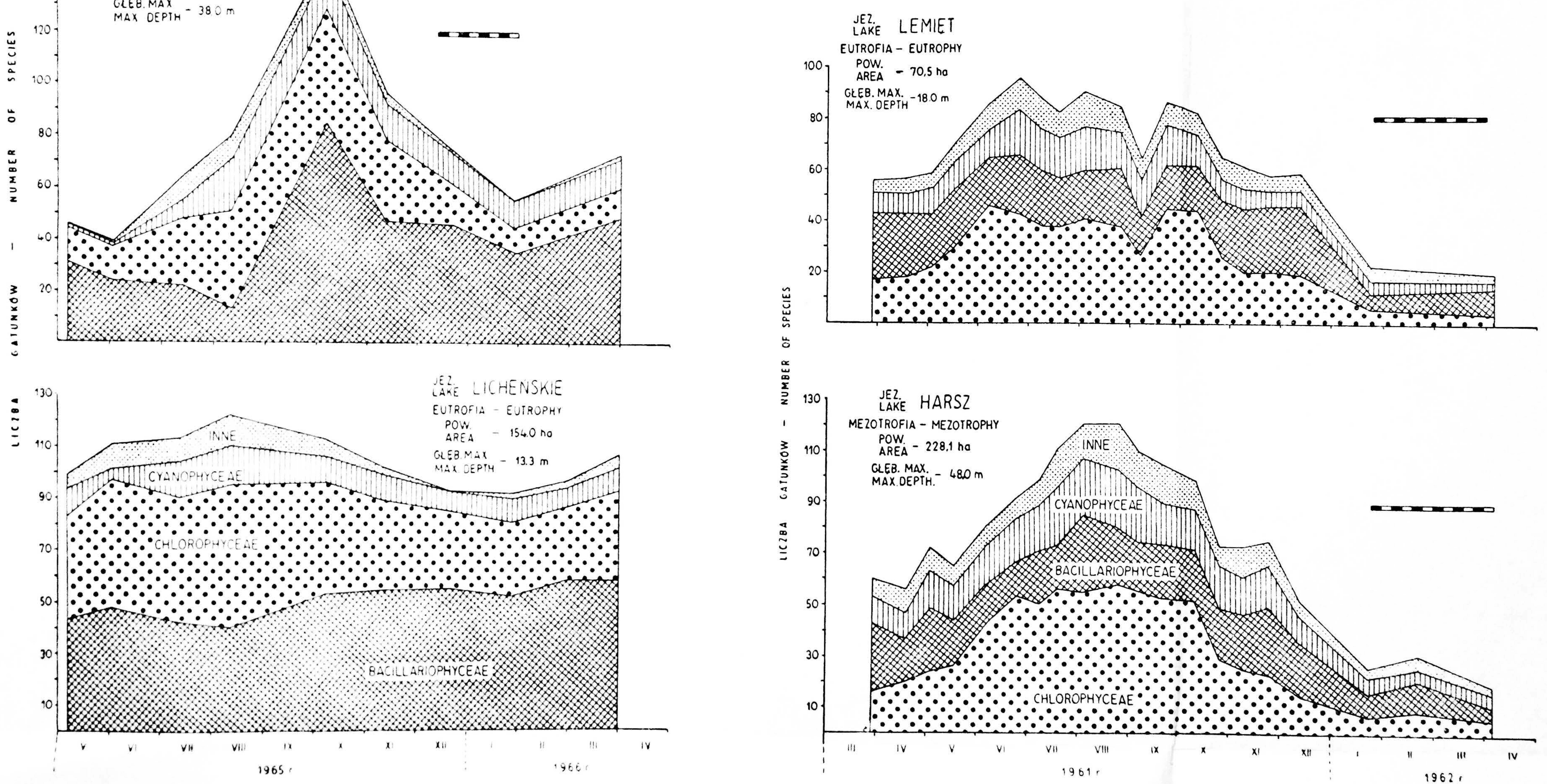

Rys. 2. Sezonowe zmiany liczby gatunków w obrębie ważniejszych gromad planktonu roślinnego w jeziorach koło konina (A) i w jeziorach mazurskich (B) Seasonal changes in number of species in the majo: phytoplankton groups in the lakes near Konin (A) and of Masurian Lake District (B) 
nów. Ma to zapewne związek z wyższymi tu zawsze, a więc korzystniejszymi dla rozwoju zielenic, temperaturami oraz ze stałym doprowadzaniem nieplanktonowych glonów z jez. Pątnowskiego.

$\mathrm{W}$ przeciwieństwie do jez. Licheńskiego w pozostałych jeziorach liczba gatunków ulegała wyraźnym wahaniom sezonowym, podobnym w obu jeziorach. Zarówno w jez. Ślesińskim, jak i w Mikorzyńskim maksimum liczby składników fitoplanktonu przypadło na październik przy temperaturach $16,0^{\circ} \mathrm{C}$ i $17,5^{\circ} \mathrm{C}$, a nie jak w jeziorach mazurskich przy maksymalnych temperaturach $\mathrm{w}$ okresie lata. W obu jeziorach konińskich było ono spowodowane zwiększonym udziałem głównie okrzemek, w mniejszym stopniu zielenic. W świetle powyższych danych wobec dużego udziału obecnych w planktonie obu jezior nieplanktonowych okrzemek nasuwa się przypuszczenie, że dostały się one w tym czasie do strefy wolnej wody na skutek silniejszej działalności wiatrów powodując wzrost ogólnej liczby komponentów fitoplanktonu. Za przypuszczeniem tym przemawia między innymi fakt zaawansowania już w tym czasie cyrkulacji jesiennej.

Minima ogólnej liczby gatunków przypadały na koniec stycznia, a więc na okres, kiedy jeziora już drugi miesiąc pozostawały pod pokrywą lodową.

Warto zwrócić uwagę na fakt, że liczba gatunków zielenic utrzymywała się $\mathrm{w}$ jeziorach konińskich na tym samym poziomie przez cały rok. Zarówno w jez. Licheńskim bogatym w zielenice, jak w jeziorach Ślesińskim i Mikorzyńskim uboższym w te glony. O ile w jez. Licheńskim liczba gatunków zielenic nie ustępowała liczbie gatunków okrzemek, w pozostałych jeziorach okrzemki były na ogół znacznie bogatsze w gatunki niż zielenice.

W porównaniu z jeziorami konińskimi jeziora mazurskie (ryc. 2) różniły się przede wszystkim znaczną przewagą zielenic nad okrzemkami zaznaczającą się niemal przez cały okres wegetacji oraz wyraźnym wzrostem liczby komponentów fitoplanktonu, głównie zielenic w najcieplejszym okresie roku. W jeziorach Lemięt i Harsz zielenice ulegały znacznym wahaniom sezonowym. W żadnym $\mathrm{z}$ jezior konińskich nie obserwowano tak wyraźnych różnic w liczbie gatunków tej gromady.

Prześledzono zależność między liczbą jedn. taksonomicznych glonów, a temperaturą powierzchniową wody w poszczególnych jeziorach konińskich oraz dla porównania również w jeziorach mazurskich. Ponieważ wśród okrzemek tak licznie reprezentowanych w jeziorach konińskich przeważały naroślinne i denne gatunki, których obecność, względnie nieobecność $\mathrm{w}$ planktonie nie jest bezpośrednio związana $\mathrm{z}$ temperaturą wody, obok wykresu uwzględniającego wszystkie gromady fitoplanktonu (ryc. 3) przedstawiono drugi wykres, na którym pominięto okrzemki (ryc. 4). 

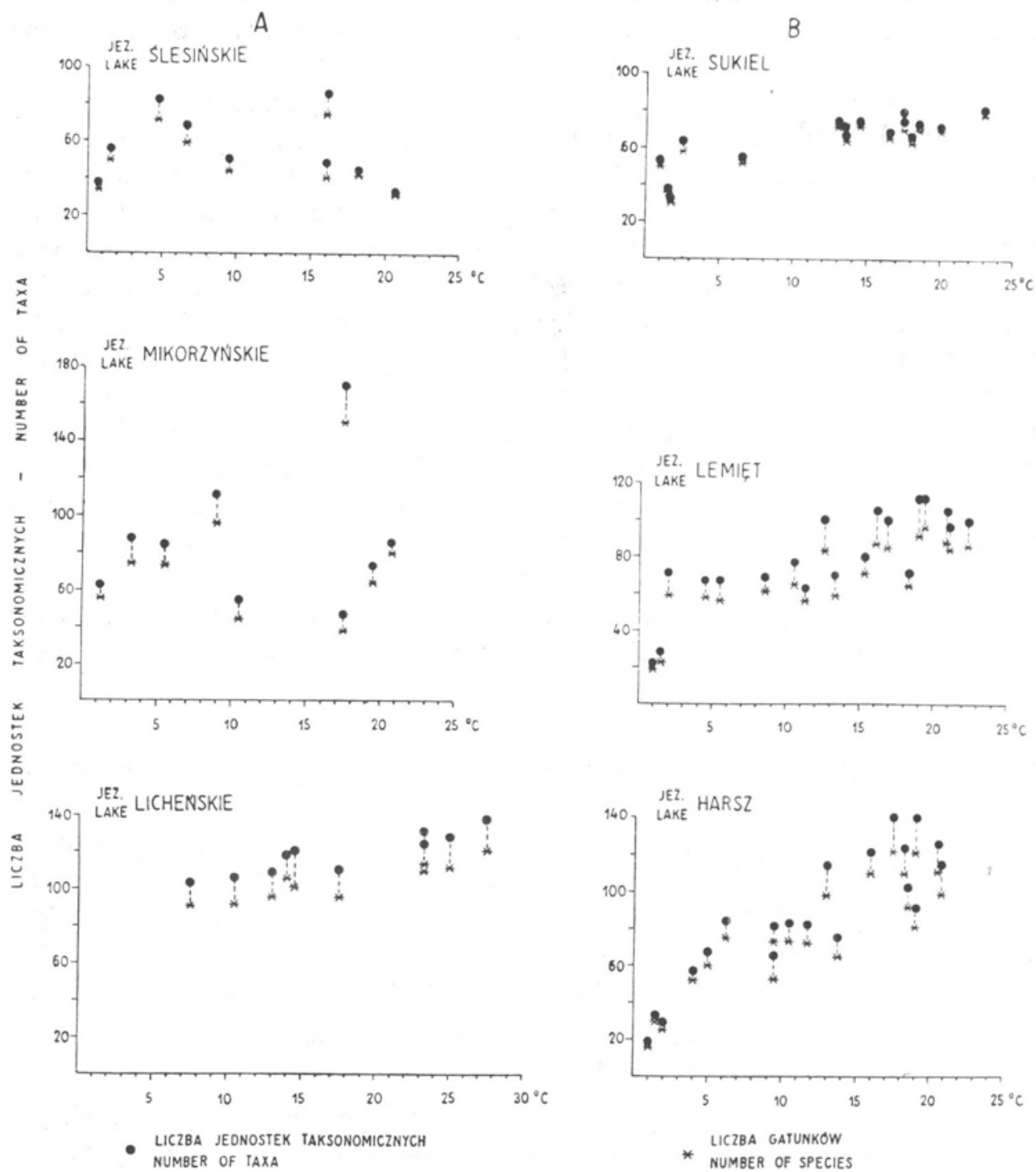

Rys. 3. Zależność między liczbą jednostek taksonomicznych glonów a temperaturą powierzchniową wody w jeziorach koło Konina (A) i w jeziorach mazurskich (B) Relation between the number of taxa of Algae and the surface water temperature in lakes near Konin (A) and those of the Masurian Lake District (B)

Zarówno przy uwzględnieniu okrzemek, jak również przy ich wyłączeniu zaznacza się w obu grupach jezior wyraźna korelacja między bogactwem jakościowym fitoplanktonu, a temperaturą wody. Szczególnie ostro zaznacza się ona przy pominięciu okrzemek. Najwyraźniejszą korelację zaobserwowano w jez. Licheńskim, w którym w miarę wzrostu 

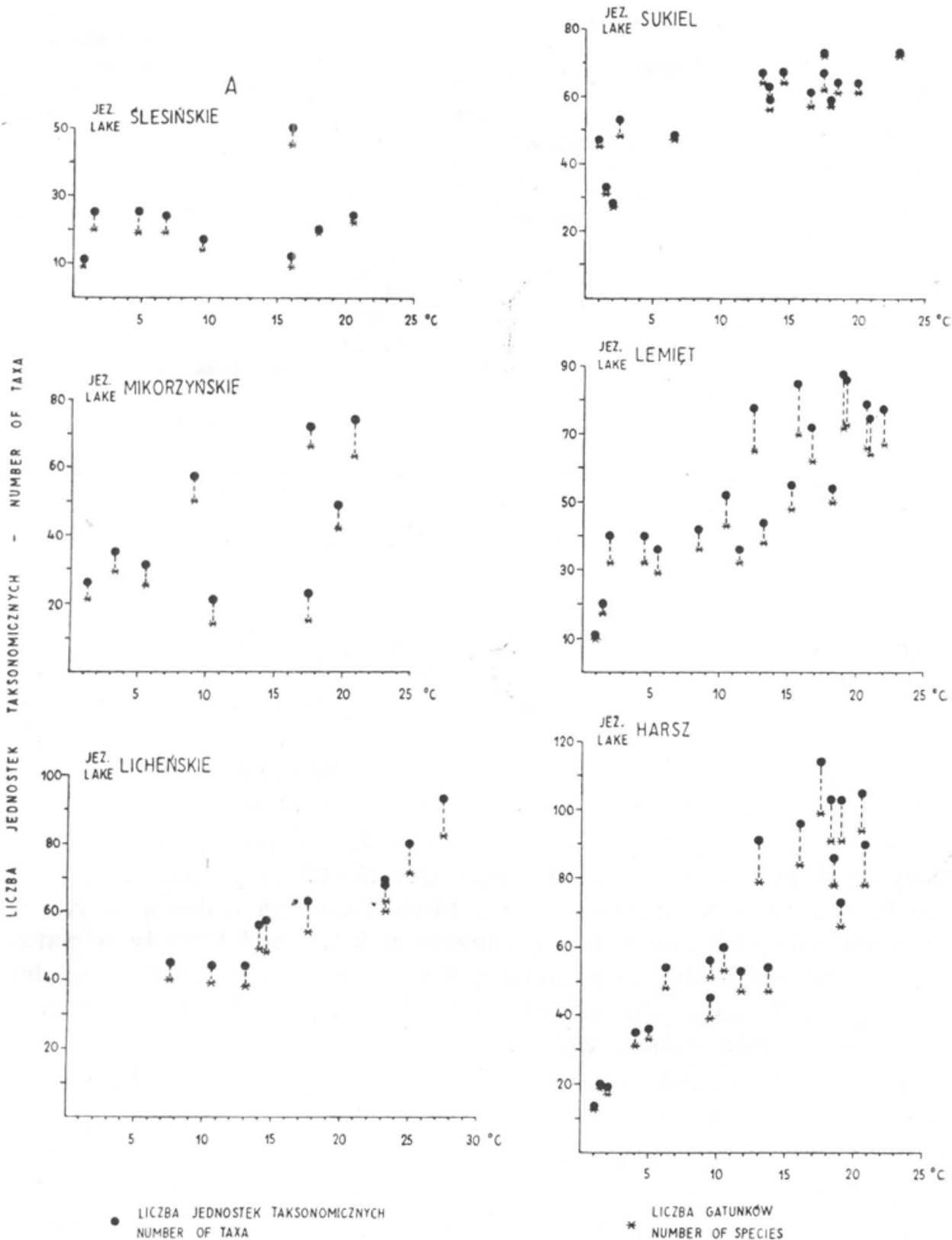

Rys. 4. Zależność między liczbą jednostek taksonomicznych glonów (z wylączeniem okrzemek) a temperaturą powierzchniową wody w jeziorach koło Konina (A) i $w$ jeziorach mazurskich (B)

Relation between the number of taxa of Algae (excl. Bacillariophyceae) and the surface water temperature in lakes near Konin (A) and those of the Masurian Lake District (B) 


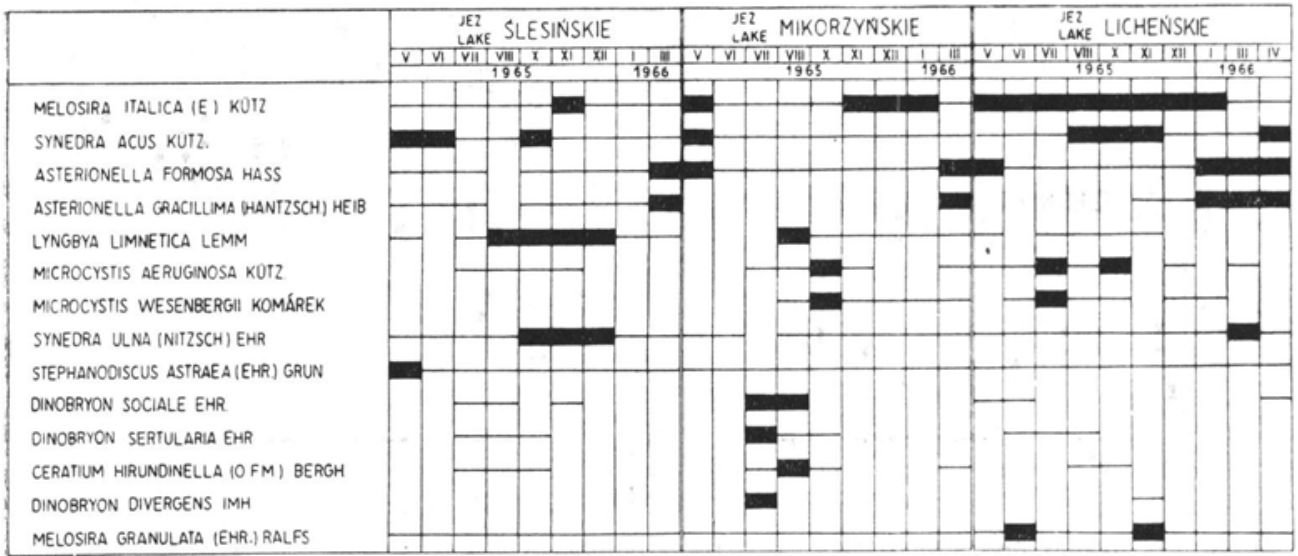

MELOSIRA GRANULATA (EHR.) RALFS

Rys. 5. Gatunki, które przynajmniej raz dominowały w siatkowym planktonie roślinnym jezior koło Konina

Species which were found at least in one phytoplankton sample as dominant

temperatury notowano coraz większą liczbę komponentów fitoplanktonu. Szczególnie wyraźnie zaznacza się ona w odniesieniu do zielenic. Zasługuje na uwagę fakt, że wzrostowi temperatury przekraczającemu górne granice temperatur spotykanych w ,normalnych” jeziorach towarzyszyło dalsze zwiększanie się ogólnej liczby jedn. taksonomicznych glonów, a przede wszystkim zielenic, głównie z rzędu Chlorococcales.

Florę glonów w stawach o temperaturze sztucznie podwyższonej, wahającej się w podobnym zakresie temperatur $\left(7-29^{\circ} \mathrm{C}\right)$ co jez. Licheńskie badała w 1960 r. Kadłubowska. Stwierdziła ona tylko sporadyczne występowanie nielicznych tam gatunków zielenic, podczas gdy w naturalnych stawach spotykała je obificie. $\mathrm{K}$ a d ł u b o ws k a znalazła w ciepłym stawie 20 gatunków zielenic, natomiast w jez. Licheńskim stwierdzono aż 111 jedn. takson. zielenic w tym 87 gatunków.

Spośród 305 gatunków znalezionych w jeziorach konińskich wyróżniono zaledwie 14 gatunków planktonowych, które dominowały pod względem liczebności osobników w różnych okresach i różnych jeziorach nad pozostałymi (ryc. 5). Następujące gatunki dominowały we wszystkich jeziorach: Melosira italica, Synedra acus, Asterionella formosa, A. gracillima. Charakterystycznymi natomiast dominantami były: dla jez. Licheńskiego - Melosira granulata, dla jez. Mikorzyńskiego - Dinobryon divergens, D. sertularia, D. sociale oraz Ceratium hirundinella, a dla jez. Ślesińskiego Stephanodiscus astraea. W obu cieplejszych jeziorach Licheńskim i Mikorzyńskim dominowały również sinice Microcystis aeruginosa i $M$. Wesenbergii. 


\section{Streszczenie}

W okresie od V.1965 do IV.1966 r. przeprowadzono wstępną ocenę składu gatunkowego planktonu roślinnego trzech jezior okolic Konina: Licheńskiego, Mikorzyńskiego, Slesińskiego (tab. 1) charakteryzujący.ch się różną temperaturą spowodowaną działalnością elektrowni Konin. Najwyższe temperatury wody wykazywało jez. Licheńskie $\left(7,4-27,5^{\circ} \mathrm{C}\right)$, najniższe, ,normalne”, jez. Slesińskie $\left(0,8-20,7^{\circ} \mathrm{C}\right)$. W różnych sezonach różnice temperatur między obu tymi jeziorami wynosiły $5,9-$ $9,6^{\circ} \mathrm{C}$, zaś między jez. Mikorzyńskim a Slesińskim $0,2-2,2^{\circ} \mathrm{C}$.

We wszystkich trzech jeziorach podczas całego okresu badań znaleziono 305 gatunków, a uwzględniając odmiany i formy 414 jedn. takson. glonów. Największą ich liczbę obejmowały okrzemki $(44 \%)$, drugie miejsce zajmowały zielenice $(34 \%)$, trzecie sinice $(11 \%)$. Udział pozostałych gromad był niewielki.

Wśród okrzemek zdecydowanie przeważały gatunki epifityczne i denne stanowiące przypadkowy składnik planktonu. Przypuszczalnie dostały się one do strefy wolnej wody na drodze mechanicznej na skutek mieszania wody, bądź też w przypadku jez. Licheńskiego i Mikorzyńskiego - zostały wniesione przez wody zrzutowe $\mathrm{z}$ płytkiego, bogatego $\mathrm{w}$ roślinność wyższą, silnie falującego jez. Pątnowskiego, z którego woda jest pobierana do elektrowni.

Największą liczbę komponentów fitoplanktonu (285) stwierdzono w jez. Licheńskim, najniższą (197) w jez. Slesińskim (ryc. 1), co wiązało się z dużymi różnicami pod względem udziału zielenic, których największą liczbę znaleziono w najcieplejszym jez. Licheńskim, najniższą natomiast w najzimniejszym jez. Slesińskim. Liczba gatunków glonów w jez. Licheńskim była względnie stała w ciągu całego roku, w przeciwieństwie do pozostałych jezior, w których ulegała znacznym wahaniom sezonowym (ryc. 2).

Najwyraźniejszą korelację między liczbą jedn. takson. glonów a temperaturą powierzchniową wody (ryc. 3 i 4) zaobserwowano w jez. Licheńskim, w którym w miarę wzrostu temperatury notowano coraz większą liczbę komponentów fitoplanktonu, zwłaszcza zielenic.

Pod względem liczebności osobników 14 gatunków planktonowych występowało w różnych okresach i różnych jeziorach w roli dominantów (ryc. 5). Następujące gatunki dominowały we wszystkich jeziorach: Melosira italica (Ehr.) Kütz., Synedra acus Kütz., Asterionella formosa Hass., A. gracillima (Hantzsch) Heib. Charakterystycznymi natomiast dominantami były: dla jez. Licheńskiego Melosira granulata (Ehr.) Ralfs, dla jez. Mikorzyńskiego Dinobryon divergens Imh., D. sertularia Ehr., D. sociale Ehr. oraz Ceratium hirundinella (O.F.M.) Bergh, a dla jez. Slesińskiego Stephanodiscus astrea (Ehr.) Grun. W obu cieplejszych jeziorach, Licheńskim i Mikorzyńskim, dominowały również sinice Microcystis aeruginosa Kütz. i $M$. Wesenbergii Kom.

Instytut Rybactwa Sródlądowego Olsztyn-Kortowo

(Wplynęło dn. 19.10 .1967 r.)

\section{SUMMARY}

A preliminary evaluation of the specific composition of phytoplankton was performed within the period May 1965 - April 1966 in the following three lakes in the environs of Konin: Licheńskie, Mikorzyńskie and Slesińskie (Table I) characterized by different temperatures owing to the activity of the thermoelectric plant in Konin. The material for investigation was collected with a net of bolting 
cloth No. 25 at monthly intervals. The highest temperature range $7.4-27.5^{\circ} \mathrm{C}$ occurred in the Licheńskie lake which receives directly the water warmed by the thermoelectric plant in Konin. The Lake Slesińskie showed the lowest "normal" temperature $\left(0.8-20.7^{\circ} \mathrm{C}\right)$ since it had no contact with the waste water from the plant. The difference in temperature between the two lakes varied in dependence on the season within $5.9-9.6^{\circ} \mathrm{C}$.

The lake Mikorzyńskie was but slightly influenced by the warm waste water. The difference in temperature between its waters and those of Slesińskie lake was in various periods $0.2-2.2^{\circ} \mathrm{C}$.

In all three lakes during the investigation period 305 species of algae were found, and if we take into account varieties and forms, 414 taxa were identified. The greatest number of taxa was observed among diatoms $\left(44^{\circ} \%\right)$, second Chlorophyta $(34 \%)$ and third Cyanophyta $(11 \%)$. The contribution of other algae was but slight.

Similar relations were found in the individual lakes.

Among diatoms epithytic and benthic species, only occasionally found in the plankton prevailed. The latter probably were carried into the zone of free water owing to mechanical stirring of the water, or in the case of the lakes Licheńskie and Mikorzyńskie, were brought by the run off from the shallow lake Patnowskie rich in higher-plants vegetation and strongly undulating. From this lake water is taken in for the electric plant.

The largest number of phytoplankton components (285) was found in the warmest Licheńskie lake, and the lowest (197) in the Slesińskie lake which was the coldest (fig. 1), the difference mainly consisting in a lower number of Chlorophyta in this lake. The number of algae species in Licheńskie lake was relatively stable within the whole annual period in contrast to the other lakes in which it showed wide seasonal variations (fig. 2). The lakes also differed widely as regards the contribution of Chlorophyta in the course of the entire period of study. The largest number of their representatives was consistently found in the warmest Licheńskie lake and the lowest in the coldest Slesińskie lake.

The relation between the number of taxa of Algae and the surface temperature of the water was studied in the particular lakes (figs. 3 and 4). The correlation was most pronounced in lake Licheńskie in which with rise of temperature an increasing number of components was noted in the phytoplankton. This was most manifest in respect to Chlorophyta. It is worth noting that a rise in temperature exceeding the upper limit of temperatures occurring in "normal" lakes is associated with a further increase - in the number of taxa of Algae, and particularly of Chlorophyta.

As regards the size of the populations, 14 plankton species were dominant at various periods in different lakes (fig. 5). The following species dominated at some time in all lakes: Melosira italica (Ehr.) Kütz, Synedra acus Kütz., Asterionella formosa Hass., A. gracillima (Hantzsch) Heib. Characteristic dominants for the particular lakes were: for Licheńskie - Melosira granulata (Ehr.) Ralfs, for Mikorzyńskie - Dinobryon divergens Imh., D. sertularia Ehr., D. sociale Ehr. and Ceratium hirundinella (O.F.M.) Bergh, for Slesińskie - Stephanodiscus astraea (Ehr.) Grun. In both the warmer lakes, Licheńskie and Mikorzyńskie the Cyanophyta, Microcystis aeruginosa Kütz. and M. Wesenbergii Kom. belonged to the dominant species. 


\section{LITERATURA}

K a d łubowska J. Z., 1960, Glony sztucznych term w Eodzi i Pabianicach, Pol. Arch. Hydrob. 8(21):223-233.

Patalas K., Wstępne obserwacje termiki wód jezior okolic Konina, w przygotowaniu.

Półtoracka J., 1966, Plankton roślinny jeziora Sukiel, Zesz. Nauk. WSR Olsztyn 21:711-731.

Półtoracka J., Zbiorowiska planktonowe w jeziorach różnego typu limnologicznego, w przygotowaniu.

W ołoszyńska J., 1913, Przyczynek do znajomości planktonu roślinnego jezior kujawskich, Spraw. Tow. Naukowego Warszawskiego 6:597-607. 